\title{
A Study of Stress Induced Biochemical Changes In Pregnancy
}

\author{
Dr.Mohana Lakshmi Jonnadula ${ }^{1}$, Dr.Sireesha Maraju², \\ ${ }^{1,2}$ Assistant Professor, Department of Biochemistry, Guntur Medical College,Guntur.
}

\begin{abstract}
:-
Aim:- To assess the risk of stress induced biochemical changes in pregnancy in view of their significant impact in developing diabetes and coronary heart disease through metabolic syndrome.

Materials and Methods:- 15 cases of Primis in first trimester.

15 cases of Primis in third trimester with normal blood pressure.

15 cases of Primis in third trimester with PIH.

Fasting blood glucose, Serum total proteins, Serum total triglycerides, Serum total cholesterol, Serum HDLCholesterol and Serum Ceruloplasmin were estimated.

Results:- There was increase in levels of fasting glucose, total triglycerides, total cholesterol and ceruloplasmin and decrease in levels of HDL and total proteins as the pregnancy is progressing with further exaggeration in PIH.The change in normal pregnancy is serum hypertriglyceridaemia which may be as high as two to three folds in third trimester over the levels in non pregnant women.A significant decrease in HDL levels were observed in pre-eclamptic pregnant women.Plasma ceruloplasmin $(C P)$ activity increased significantly $(p<0.05)$ as pregnancy progressed.There was 3.60 fold increase in risk of pre-eclampsia among women with total cholesterol > 205mg / dl and 4.15 fold increase in risk of pre-eclampsia among women with triglycerides $>133 \mathrm{mg} / \mathrm{dl}$.

Conclusion:- The present study concludes that pregnancy is a stressful condition resulting in varied biochemical changes. These changes are exaggerated when pregnant women have associated hypertension which is a risk factor of metabolic syndrome and they are possibly prone to diseases like diabetes mellitus, coronary artery diseases and stroke.
\end{abstract}

Keywords:- Metabolic syndrome, PIH, Preeclampsia, coronary artery diseases, stroke, Hypertriglyceridaemia, Ceruloplasmin.

\section{I . Introduction}

Stress is inevitable in everyday life and it affects mental and physical well-being both beneficially and detrimentally. 'Stress' was defined by Hans Selye, a physician who investigated stress as "the non-specific response of the body to any demand"1 and the cause of stress as "stressor". These stressors may be physiological or psychological. Physiological stressors like trauma, infection affect human organ systems directly through catabolic changes. Psychological stressors affect human organ systems directly via the psycho-neuro-endocrinoimmune network ${ }^{2}$ and also by modulation of human behavior. One individual's perception of a particular stressor will differ from another's. Factors affecting stress perception may be related to environment and related to physical interaction of environment with the individual (objective) or related to individual feelings (subjective). Among these three factors, the individual related psychological factors (subjective) are those most directly affect the individual health.

Brain-to-immune pathway -Two major axes have been proposed in the stress response: The Sympathetic Adreno-Medulla pathway (SAM) and The Hypothalamus-Pituitary-Adrenal(HPA) axis.The fight or flight response and emotions are associated with increased activity in sympathetic nervous system. There are two pathways by which these sympathetic signals are conveyed to target organs. One through direct neural connections where norepinephrine acts as a neurotransmitter and the other through SAM pathway where epinephrine is released from adrenal glands and travel through blood stream. The sympathetic neural fibers descend from brain into a neural terminal both in primary and secondary lymphoid tissues. Immune cells also express catecholamine receptors. So catecholamines,norepinephrine and epinephrine activate immune response including an increase of NK cells and cytotoxic T-cells ${ }^{3}$. Cortisol the main secreted hormone in HPA axis is the major stress related hormone ${ }^{4}$. Major immune organs like spleen and thymus are rich in cortisol receptors. There is consistent order of response in change levels of mediators between SAM and HPA axes, i.e. an increase of cortisol levels was observed after an increase of catecholamine levels. This suggests that catecholamines may promote cortisol secretion so that the two main axes of brain-to-immune pathway communicate with each other. Pro-inflammatory cytokines like IL-1, IL-6 and TNF- $\alpha$ can activate SAM and HPA axes ${ }^{5}$. IL-1 particularly was shown to be capable of increasing permeability of blood brain barrier. Cytokines released are affecting peripheral nerves and brain as well as peripheral immune cells. These pro-inflammatory cytokines are also 
demonstrated to initiate sickness behavior like fatigue, sleepiness and anorexia. This suggests that there is direct interaction between immune cells and brain.So it is proposed that intercellular interactions and intracellular mechanisms in each level of psycho-neuro-endocrino-immune network enable the immune system to maintain homeostasis in health.

Acute stress is defined as stress that has its effects within one day.In the nervous system, acute stress activates the secretary neurons through aminergic and GABA-ergic innervations in the autonomic nervous system $^{6}$. In the immune system acute stress increases the number of NK-cells in the blood stream and NK cytotoxic activity. Acute stress acting through the SAM and HPA axes 1) Promotes inflammation as an alarm response which in turn stimulates SAM axis to produce catecholamines which in turn promotes the secretion of pro-inflammatory cytokines.

2) Increases the levels of cortisol which can counteract the alarm signal and suppress activation of the immune system. Cortisol has been considered as main stress hormone which can suppress the immune response by affecting targets mainly through its glucocorticoid receptors.

Sustained stress is defined as stress that has its effects for more than one day, i.e. over more than one circadian rhythm. Sustained stress induces various changes in psycho-neuro-endocrino immune network. It increases blood brain barrier permeability and inhibitory GABA-ergic nervous activity was attenuated under sustained stress ${ }^{7}$. Sustained stress has been demonstrated to alter tissue specific distribution of lymphocyte subpopulation and specifically peripheral NK-cell levels are decreased ${ }^{8}$. Mechanisms which contribute to suppress cellular immune responses are 1) Due to sustained exposure to high levels of cortisol is associated with multiple positive feedback loops in HPA axes and it exacerbate the imbalance of interactions within psycho-neuroendocrino immune network. 2) Accumulated negative feedbacks from repetitive responses in both SAM and HPA axes result in impaired reactions in their hormone secretions. Any type of stress either physiological or psychological triggers a characteristic hypermetabolic state in which resting energy expenditure is increased along with body temperature. The extent and pattern of metabolic changes vary with the type as well as severity of stress experienced. The stress syndrome shows certain common features like 1) Marked increase in release of amino acids from tissue proteins particularly from skeletal muscle.2) Increase in hepatic gluconeogenesis resulting in hyperglycemia. 3) Increase in synthesis of specific proteins for example those proteins involved in acute phase of inflammatory response and those concerned with repair of injured tissue.

Carbohydrate Metabolism:-Tissue injury prompts increased levels of cytokines, glucagon, cortisol, catecholamines and insulin. In presence of stress insulin does not display its usual spectrum of actions. Insulin resistance in stress is promoted by high concentrations of counter regulatory hormones. They minimize glucose utilization by tissues resulting in hyperglycemia.

Hyperglycemia $\uparrow \mathrm{ATP}, \uparrow \mathrm{NADH} \rightarrow \downarrow$ Glucose utilisation $\rightarrow \downarrow$ Glycolysis

The other effects of stress on carbohydrate metabolism are Gluconeogenesis and increased Glycogenolysis.

Lipid Metabolism:-Increase in oxaloaceticacid and acetyl CoA $\rightarrow \uparrow$ Cholesterol synthesis

Protein Metabolism:- Cortisol, Catecholamines $\rightarrow \uparrow$ protein degradation $\rightarrow \uparrow$ Proteolysis $\rightarrow \uparrow \uparrow$ amino acids. Amino acids released enter the liver and these are responsible for increased Apo-protein synthesis, increased triglyceride synthesis and increase in cholesterol esterification. $\uparrow$ Apo-protein synthesis $\rightarrow \uparrow \uparrow$ Lipoprotein synthesis. This increased lipoprotein synthesis in stress is responsible for hyper lipoproteinemia. Stress when managed properly provides us the drive to meet new challenges. However when physical or emotional stress builds up to uncomfortable levels it can be harmful for pregnant woman. In short, a high level of stress can cause fatigue, sleeplessness, anxiety, poor appetite or overeating, headaches and backaches. When a high level of stress continues for a long period it may contribute to potentially serious health problems such as lowered resistance to infectious diseases, high blood pressure and heart diseases. Studies also suggest that high levels of stress may pose special risks during pregnancy. Pregnancy related discomforts such as nausea, fatigue, frequent urination, backache can be stressful in pregnant women. Hormonal changes are also responsible for mood swings experienced during pregnancy.

Effects of stress on pregnancy:--1) Preterm labour:- Corticotrophin Releasing Hormone (CRH) is the first hormone our brain secretes when we are under stress. Pregnant women who experience high levels of stress have high levels of $\mathrm{CRH}$ in their blood ${ }^{9}$. CRH released prompts the body to release chemicals called prostaglandins which trigger uterine contractions. This is the reason for preterm labour.2) Low birth weight:Stress related hormones such as norepinephrine constrict blood flow to placenta ${ }^{10}$. So the baby may not receive the nutrients and oxygen it needs for optimal growth. This results in low birth weight.3) Alterations in brain development:- Exposure to uncontrollable stress during pregnancy results in a heightened elevation of plasma corticosterone $^{11}$. This was accompanied by a significant decrease in maternal levels of corticosteroid binding globulin which suggest increase circulating levels of free corticosterone .In unbound state corticosterone may be highly effective in producing alterations in brain development of offspring. Chronic stress causes decreased weight gain, higher blood pressure, lower endothelial-derived relaxing factor and lower fetal weight. 
Another important stress induced effect in pregnancy is PIH (pregnancy induced hypertension). Preeclampsia is a more serious form of PIH. It is diagnosed when a mother's blood pressure is higher than $140 / 90$ in the last 20wks of pregnancy. An abnormal lipid profile is known to be strongly associated with atherosclerotic cardiovascular disease and has a direct effect on endothelial dysfunction. Most important feature in toxemia of pregnancy is hypertension which is supposed to be due to vasospastic phenomenon in kidney, uterus, placenta and brain. Altered lipid synthesis leading to decrease in $\mathrm{PGI}_{2} / \mathrm{TxA}_{2}$ ratio is also supposed to be an important way of pathogenesis in $\mathrm{PIH}^{12}$. Thus abnormal lipid metabolism seems important in pathogenesis of $\mathrm{PIH}$. The hormonal imbalance is a prime factor for etiopathogenesis of PIH and this endocrinal imbalance is well reflected in alteration of serum lipid profile. Women who develop hypertension during pregnancy face a higher risk for stroke, coronary heart disease, hypertension and microalbuminuria later in life ${ }^{13}$. Women in whom PIH eventually develops are more likely to enter pregnancy overweight and some of the risk factors characterizing atherosclerosis such as dyslipidaemia (hypertriglyceridemia, low levels of HDL, and raised small LDL cholesterol $)^{14}$, insulin resistance ${ }^{15}$ and endothelial dysfunction ${ }^{16}$ are demonstrated. These metabolic aberrations like increased adiposity, dyslipidaemia, hyperglycemia and elevated blood pressure are reminiscent of metabolic syndrome. This syndrome is considered as an independent risk factor for cardiovascular disease. ${ }^{17}$ Based on documented evidence the women who suffer from PIH present a syndrome similar to metabolic syndrome and these women seem at increased risk of developing cardiovascular disease later in life.

\section{Materials and methods}

Controls- For the present study women who were selected were primis of first trimester without hypertension, proteinuria and edema who were taken as Group A(15 cases).

Cases- In this study women who were primis in third trimester were divided into two groups (B \& C). In Group B (15 cases) women selected were with gestational age between 28 weeks and 39 weeks without hypertension, proteinuria and edema. In Group C (15 cases) women selected were with gestational age between 28 weeks and 39 weeks with hypertension, proteinuria and with or without edema. All cases and controls that were pregnant were asked to come to biochemistry laboratory on overnight fasting at 9 A.M. After brief clinical examination i.e. taking relevant history, recording blood pressure, measuring weight; blood sample was taken for the measurements of following parameters-- Estimation of glucose, Serum total proteins, Lipid profile(Total triglycerides, Total cholesterol,HDL ), Ceruloplasmin levels.

\section{RESULTS}

Table 1: GROUP A: Primis in first trimester

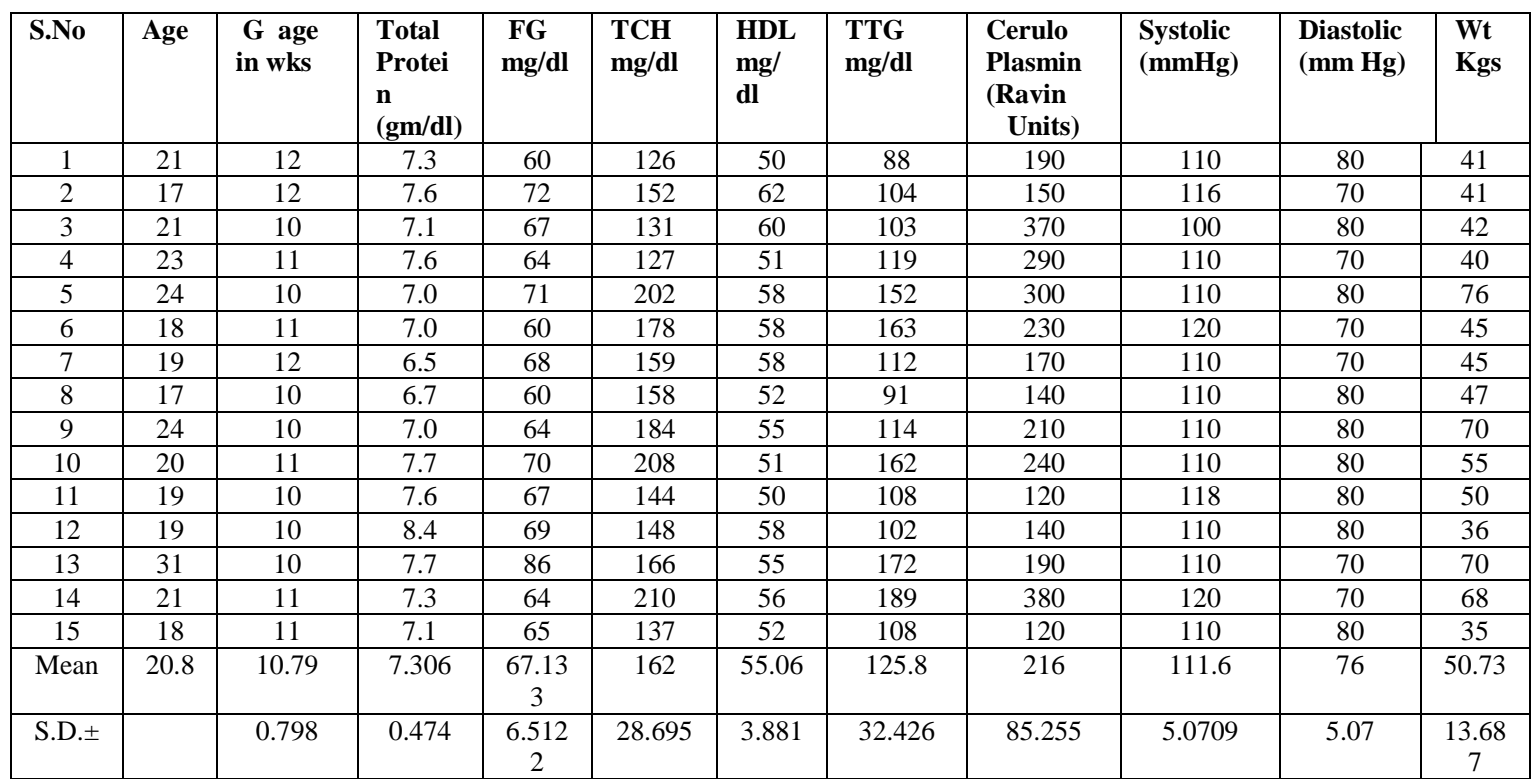


Table 2: GROUP B: Primis in third trimester with normal blood pressure

\begin{tabular}{|c|c|c|c|c|c|c|c|c|c|c|c|}
\hline S.No & Age & $\begin{array}{l}\text { G age } \\
\text { in wks }\end{array}$ & $\begin{array}{l}\text { Total } \\
\text { Protein } \\
(\mathrm{gm} / \mathrm{dl})\end{array}$ & $\begin{array}{l}\text { FG } \\
\mathrm{mg} / \mathrm{dl}\end{array}$ & $\begin{array}{l}\text { TCH } \\
\mathrm{mg} / \mathrm{dl}\end{array}$ & $\begin{array}{l}\text { HD } \\
\text { L } \\
\text { mg/ } \\
\text { dl } \\
\end{array}$ & $\begin{array}{l}\text { TTG } \\
\text { mg/dl }\end{array}$ & $\begin{array}{l}\text { Cerulo } \\
\text { Plasmin } \\
\text { (Ravin } \\
\text { Units) } \\
\end{array}$ & $\begin{array}{l}\text { Systolic } \\
\text { (mmHg) }\end{array}$ & $\begin{array}{l}\text { Diastolic } \\
(\mathrm{mm} \mathrm{Hg})\end{array}$ & $\begin{array}{l}\text { Wt } \\
\text { Kg } \\
\text { s }\end{array}$ \\
\hline 1 & 20 & 38 & 6.5 & 64 & 242 & 56 & 204 & 390 & 110 & 70 & 57 \\
\hline 2 & 22 & 36 & 5.2 & 71 & 214 & 50 & 168 & 480 & 110 & 70 & 70 \\
\hline 3 & 28 & 36 & 7.3 & 77 & 250 & 48 & 134 & 400 & 110 & 70 & 65 \\
\hline 4 & 20 & 36 & 5.0 & 72 & 180 & 48 & 175 & 420 & 100 & 70 & 50 \\
\hline 5 & 25 & 34 & 7.0 & 68 & 184 & 45 & 162 & 360 & 110 & 80 & 55 \\
\hline 6 & 20 & 39 & 6.4 & 80 & 192 & 50 & 220 & 400 & 120 & 80 & 56 \\
\hline 7 & 18 & 39 & 6.2 & 78 & 130 & 47 & 218 & 470 & 120 & 80 & 45 \\
\hline 8 & 20 & 38 & 6.3 & 82 & 177 & 50 & 123 & 540 & 120 & 70 & 39 \\
\hline 9 & 20 & 39 & 6.0 & 81 & 183 & 46 & 140 & 380 & 120 & 80 & 50 \\
\hline 10 & 19 & 39 & 6.5 & 75 & 185 & 45 & 150 & 230 & 120 & 70 & 51 \\
\hline 11 & 18 & 37 & 7.0 & 76 & 193 & 55 & 216 & 500 & 120 & 70 & 54 \\
\hline 12 & 20 & 37 & 6.2 & 82 & 176 & 50 & 182 & 250 & 100 & 60 & 55 \\
\hline 13 & 20 & 38 & 6.6 & 71 & 198 & 57 & 219 & 410 & 110 & 80 & 56 \\
\hline 14 & 19 & 33 & 5.8 & 74 & 150 & 48 & 212 & 420 & 110 & 80 & 50 \\
\hline 15 & 17 & 36 & 5.6 & 73 & 209 & 45 & 217 & 330 & 120 & 80 & 65 \\
\hline Mean & 20.4 & 37 & 6.24 & 74.93 & $\begin{array}{c}190.8 \\
6 \\
\end{array}$ & $\begin{array}{c}49.3 \\
3 \\
\end{array}$ & 182.66 & 406 & 113.33 & 74 & 54.5 \\
\hline S.D. \pm & & 1.85 & 0.6467 & 5.2707 & $\begin{array}{c}30.56 \\
8\end{array}$ & $\begin{array}{c}3.92 \\
1\end{array}$ & 34.933 & 84.588 & 7.2374 & 6.3245 & $\begin{array}{c}7.90 \\
9\end{array}$ \\
\hline
\end{tabular}

\begin{tabular}{|c|c|c|c|c|c|c|c|c|c|c|c|}
\hline S.No & Age & $\begin{array}{l}\text { G age } \\
\text { in wks }\end{array}$ & $\begin{array}{l}\text { Total } \\
\text { Protei } \\
\text { n } \\
(\mathrm{gm} / \mathrm{dl})\end{array}$ & $\begin{array}{l}\text { FG } \\
\mathrm{mg} / \mathrm{dl}\end{array}$ & $\begin{array}{l}\text { TCH } \\
\mathrm{mg} / \mathrm{dl}\end{array}$ & $\begin{array}{l}\text { HDL } \\
\text { mg/ } \\
\text { dl }\end{array}$ & $\begin{array}{l}\text { TTG } \\
\mathrm{mg} / \mathrm{dl}\end{array}$ & $\begin{array}{l}\text { Cerulo } \\
\text { Plasmin } \\
\text { (Ravin } \\
\text { Units) }\end{array}$ & $\begin{array}{l}\text { Systolic } \\
\text { (mmHg) }\end{array}$ & $\begin{array}{l}\text { Diastolic } \\
\text { (mm Hg) }\end{array}$ & $\begin{array}{l}\text { Wt } \\
\text { Kgs }\end{array}$ \\
\hline 1 & 21 & 38 & 4.2 & 90 & 210 & 45 & 216 & 550 & 140 & 90 & 50 \\
\hline 2 & 19 & 39 & 5.7 & 85 & 158 & 42 & 194 & 640 & 130 & 90 & 56 \\
\hline 3 & 22 & 34 & 6.8 & 70 & 228 & 42 & 171 & 480 & 140 & 90 & 50 \\
\hline 4 & 20 & 36 & 4.5 & 88 & 205 & 45 & 174 & 600 & 130 & 100 & 66 \\
\hline 5 & 19 & 37 & 4.2 & 98 & 255 & 46 & 189 & 490 & 140 & 100 & 70 \\
\hline 6 & 22 & 32 & 3.5 & 80 & 225 & 45 & 234 & 550 & 150 & 100 & 54 \\
\hline 7 & 19 & 36 & 6.5 & 78 & 161 & 42 & 209 & 390 & 140 & 100 & 57 \\
\hline 8 & 22 & 37 & 6.0 & 100 & 248 & 45 & 220 & 390 & 150 & 110 & 52 \\
\hline 9 & 19 & 37 & 6.8 & 74 & 243 & 44 & 202 & 460 & 130 & 100 & 50 \\
\hline 10 & 21 & 36 & 5.6 & 84 & 233 & 42 & 248 & 360 & 150 & 110 & 50 \\
\hline 11 & 20 & 38 & 6.0 & 76 & 241 & 46 & 217 & 500 & 170 & 100 & 65 \\
\hline 12 & 22 & 36 & 4.6 & 102 & 210 & 43 & 214 & 620 & 130 & 110 & 55 \\
\hline 13 & 21 & 37 & 5.2 & 82 & 215 & 46 & 190 & 540 & 140 & 100 & 48 \\
\hline 14 & 20 & 36 & 3.8 & 68 & 240 & 45 & 236 & 580 & 150 & 100 & 60 \\
\hline 15 & 20 & 38 & 4.6 & 106 & 190 & 43 & 210 & 620 & 130 & 90 & 52 \\
\hline Mean & 20.4 & 36.46 & 5.2 & 85.4 & 217.46 & 44.06 & 208.26 & 518 & 141.33 & 99.33 & 55.6 \\
\hline S.D. \pm & & 1.725 & 1.0875 & 11.81 & 29.539 & 1.579 & 22.089 & 89.567 & 11.254 & 7.0373 & 6.74 \\
\hline
\end{tabular}

Table 3: GROUP C: Primis in third trimester with PIH

Table: 4

GROUP A : Primis in first trimester

GROUP B : Primis in third trimester with normal blood pressure

\begin{tabular}{|c|c|c|c|c|c|c|}
\hline & \multicolumn{2}{|c|}{ GROUP A } & \multicolumn{2}{c|}{ GROUP B } & \multirow{2}{*}{$\begin{array}{c}\text { P } \\
\text { value }\end{array}$} & \\
\cline { 2 - 6 } & Average & S.D. & Average & S.D. \pm & Significance \\
\hline FG & 67.133 & 6.5122 & 74.93 & 5.2707 & $<0.01$ & Significant \\
\hline $\begin{array}{c}\text { Total } \\
\text { Cholesterol }\end{array}$ & 162 & 28.695 & 190.86 & 30.568 & $<0.05$ & $\begin{array}{c}\text { Highly } \\
\text { Significant }\end{array}$ \\
\hline $\begin{array}{c}\text { Total } \\
\text { Triglycerides }\end{array}$ & 125.8 & 32.426 & 182.66 & 34.933 & $<0.001$ & Significant \\
\hline HDL & 55.06 & 3.881 & 49.33 & 3.921 & $<0.01$ & $\begin{array}{c}\text { Highly } \\
\text { Significant }\end{array}$ \\
\hline Total proteins & 7.3 & 0.474 & 6.24 & 0.6467 & $<0.001$ & $\begin{array}{c}\text { Highly } \\
\text { Significant }\end{array}$ \\
\hline Ceruloplasmin & 216 & 85.255 & 406 & 84.588 & $<0.001$ & \\
\hline
\end{tabular}


Table:5

GROUP B : Primis in third trimester with normal blood pressure GROUP C: Primis in third trimester with PIH

\begin{tabular}{|c|c|c|c|c|c|c|}
\hline & \multicolumn{2}{|c|}{ GROUP B } & \multicolumn{2}{c|}{ GROUP C } & \multirow{2}{*}{$\begin{array}{c}\text { P } \\
\text { value }\end{array}$} & Significance \\
\cline { 2 - 6 } & Average & S.D. & Average & S.D. & Sagnificant \\
\hline FG & 74.93 & 5.2707 & 85.4 & 11.818 & $<0.01$ & Significant \\
\hline $\begin{array}{c}\text { Total } \\
\text { Cholesterol }\end{array}$ & 190.86 & 30.568 & 217.46 & 29.539 & $<0.05$ & Significant \\
\hline $\begin{array}{c}\text { Total } \\
\text { Triglycerides }\end{array}$ & 182.66 & 34.933 & 208.26 & 22.089 & $<0.05$ & $\begin{array}{c}\text { Highly } \\
\text { Significant }\end{array}$ \\
\hline HDL & 49.33 & 3.921 & 44.06 & 1.579 & $<0.001$ & Significant \\
\hline Total proteins & 6.24 & 0.6467 & 5.2 & 1.0875 & $<0.01$ & $\begin{array}{c}\text { Highly } \\
\text { Significant }\end{array}$ \\
\hline Systolic BP & 113.33 & 7.2374 & 141.33 & 11.254 & $<0.001$ & $\begin{array}{c}\text { Highly } \\
\text { Significant }\end{array}$ \\
\hline Diastolic BP & 74 & 6.3245 & 99.33 & 7.0373 & $<0.001$ & Significant \\
\hline Ceruloplasmin & 406 & 84.588 & 518 & 89.567 & $<0.01$ & \\
\hline
\end{tabular}

Table:6

GROUP A : Primis in first trimester

GROUP C: Primis in third trimester with PIH

\begin{tabular}{|c|c|c|c|c|c|c|}
\hline & \multicolumn{2}{|c|}{ GROUP A } & \multicolumn{2}{|c|}{ GROUP C } & \multirow{2}{*}{$\begin{array}{c}\mathrm{P} \\
\text { value }\end{array}$} & \multirow[t]{2}{*}{ Significance } \\
\hline & Average & S.D. \pm & Average & S.D. \pm & & \\
\hline FG & 67.133 & 6.5122 & 85.4 & 11.818 & $<0.001$ & $\begin{array}{c}\text { Highly } \\
\text { Significant }\end{array}$ \\
\hline $\begin{array}{c}\text { Total } \\
\text { Cholesterol }\end{array}$ & 162 & 28.695 & 217.46 & 29.539 & $<0.001$ & $\begin{array}{c}\text { Highly } \\
\text { Significant }\end{array}$ \\
\hline $\begin{array}{c}\text { Total } \\
\text { Triglycerides }\end{array}$ & 125.8 & 32.426 & 208.26 & 22.089 & $<0.001$ & $\begin{array}{c}\text { Highly } \\
\text { Significant }\end{array}$ \\
\hline HDL & 55.06 & 3.881 & 44.06 & 1.579 & $<0.001$ & $\begin{array}{c}\text { Highly } \\
\text { Significant }\end{array}$ \\
\hline Total proteins & 7.3 & 0.474 & 5.2 & 1.0875 & $<0.001$ & $\begin{array}{c}\text { Highly } \\
\text { Significant }\end{array}$ \\
\hline Systolic BP & 111.6 & 5.0821 & 141.33 & 11.254 & $<0.001$ & $\begin{array}{c}\text { Highly } \\
\text { Significant }\end{array}$ \\
\hline Diastolic BP & 76 & 5.07 & 99.33 & 7.0373 & $<0.001$ & $\begin{array}{c}\text { Highly } \\
\text { Significant }\end{array}$ \\
\hline Ceruloplasmin & 216 & 85.255 & 518 & 89.567 & $<0.001$ & $\begin{array}{c}\text { Highly } \\
\text { Significant }\end{array}$ \\
\hline
\end{tabular}

\section{Discussion}

In the current study it is seen that there was increase in levels of fasting glucose, total triglycerides, total cholesterol and ceruloplasmin and decrease in levels of HDL and total proteins as the pregnancy is progressing with further exaggeration in PIH. Catalano et $\mathrm{al}^{18}$ in their studies stated that there was a significant increase in fasting hepatic glucose production in late gestation when compared to early gestation. The increase in fasting hepatic glucose production is evidence for decreased hepatic insulin sensitivity in late gestation. The increase in fasting hepatic glucose production is believed to be necessary to provide for the increase in fasting fetal and placental glucose requirements in late gestation. Jayanta De et al in their studies showed that there is serum hypertriglyceridaemia which may be as high as two to three folds in third trimester over the levels in non pregnant women. The principle modulator of this hypertriglyceridaemia is estrogen as pregnancy is associated with hyperestrogenaemia. Estrogen induces hepatic biosynthesis of endogenous triglycerides which is carried by VLDL. Serum triglycerides concentrations also rose in PIH pregnant women ${ }^{19}$. In their studies a significant decrease in HDL levels were observed in pre-eclamptic pregnant women.

Daniel et al studied the relationship between early pregnancy plasma lipid concentrations and preeclampsia. Women who subsequently developed pre-eclampsia had $13.6 \%$ and $15.5 \%$ higher concentrations of triglycerides and LDL/HDL ratios than did control subjects with $\mathrm{p}<0.05$. The HDL cholesterol concentrations were $7.0 \%$ lower in women with pre-eclampsia than did controls. There was 3.60 fold increase in risk of preeclampsia among women with total cholesterol $>205 \mathrm{mg} / \mathrm{dl}$ and 4.15 fold increase in risk of pre-eclampsia among women with triglycerides $>133 \mathrm{mg} / \mathrm{dl}$. In his studies he concluded that early pregnancy dyslipidemia is associated with increased risk of pre-eclampsia. Smith et al studied that plasma $\mathrm{Cu}$ and plasma ceruloplasmin $(\mathrm{CP})$ activity increased significantly $(\mathrm{p}<0.05)$ as pregnancy progressed. Plasma ceruloplasmin concentration increases about 10 fold during development and further rises up to threefold during pregnancy. Elevated serum 
ceruloplasmin has been found to be a risk factor for coronary heart disease $\mathrm{e}^{20}$ and a strong correlation exists between serum ceruloplasmin and serum lipid oxidation. Isomaa et $\mathrm{al}^{21}$ established the link between the metabolic syndrome and cardiovascular disease in their studies. It has been shown that clustering of the risk factors associated with this syndrome acts synergistically resulting in a higher risk of cardiovascular disease. Prevalence of the metabolic syndrome was 3.4- fold and 4.9- fold higher in women who had PIH in their first pregnancy compared with those with normotensive pregnancy. zetabolic syndrome may play a role in the pathophysiology linking PIH to long-term cardiovascular disease ${ }^{22}$. From these studies it is suggested that the metabolic syndrome could represent the biologic link explaining the increased morbidity and mortality from later cardiovascular disease observed among women who have had PIH. These findings emphasize the importance of introducing measures to prevent, screen for, and treat the metabolic syndrome shortly after the index pregnancy among women who have had PIH.

\section{Conclusion}

From the present study it is concluded that pregnancy is a stressful condition as evidenced by changes in biochemical parameters like increase in fasting glucose, abnormal lipid profile and decrease in total protein levels as the pregnancy is progressing. These changes are exaggerated when these pregnant women have associated hypertension which is one of the risk factors of metabolic syndrome. Thus these pregnant women are possibly prone to diseases like diabetes mellitus, coronary artery diseases and stroke.

So in this study it is seen that pregnancy with hypertension is possibly associated with metabolic syndrome. By properly managing the stress in pregnancy, complications like PIH due to stress can be avoided and by properly managing the hypertension the risk of CAD and stroke in future can be reduced. So, every one especially pregnant women needs to identify subjectively the personal and work related sources of stress in their life and know effective ways to deal to minimize them thus one can lead a healthy life.

\section{References}

[1]. Selye,H. (1936). "A syndrome produced by diverse nocuous agents." Nature138:32.

[2]. Cohen,S. and Herbert,T.B. (1996). "Health psychology: psychological factors and physical from the perspective of human psychoneuroimmunology." Annu Rev Psychol 47: 113-42.

[3]. Hennig,J.,Netter,P.,et al. (2000). "Mechanisms of changes in lymphocyte numbers after psychological stress." Z Rheumatol 59 Suppl 2: II/ 43-8.

[4]. Hucklebridge,F.,Sen,S.,et al. ( 1998). "The relationship between circadian patterns of salivary cortisol and endogenous inhibitor of monoamine oxidase A. " Lif e Sci 62( 25): 2321-8.

[5]. Perlstein,R.S., Wht mall,M.H., et al. ( 1993). " Synergistic roles of Interleukin-6, Interleukin-1, Tumor Necrosis Factor in the adrenocorticotropin response to bacterial lipopolysaccharide invivo." Endocrinology 132: 946-952.

[6]. Cole,R.L. and Sawchenko,P.E. (2002). "Neurotransmitter regulation of cellular activation and neuropeptide gene expression in the paraventricular nucleus of the hypothalamus." J Neurosci 22(3): 959-69.

[7]. Verkuyl, J.M., Hemby,S.E., et al. (2004). "Chronic stress attenuates GABAergic inhibition and alters gene expression of parvocellular neurons in rat hypothalamus." European Journal of Neuroscience 20( 6): 1665-1673.

[8]. Maes,M., Stevens,W., et al. (1992). "A study on the blunted natural killer cell activity in severely depressed patients. " Life Sci 50( 7): 505-13.

[9]. Hobel,C.J., et al. Maternal plasma corticotrophin -releasing hormone associated with stress at 20 weeks' gestation in pregnancies ending in preterm delivery. American Journal of Obstetrics and Gynecology, volume 180, number 1, part 3, January 1999, pages S257-S263

[10]. McCubbin, James A., et al. Prenatal maternal blood pressure response to stress predicts birthweight and gestational age: a preliminary study. American Journal of Obstetrics and Gynecology, volume 175, number 3, September 1996, pages 706-712.

[11]. American Journal of Obstetrics and Gynecology Volume 23, Issue 6, August 1998, pages 571-581.

[12]. Robson,S.C. (1999) Hypertension and renal disease in pregnancy, In:Dewhurst's Textbook of Obstetrics and Gynaecology for postgraduates, Ed. Edmonds, D.K., $6^{\text {th }}$ edition, Blackwell Science Ltd., New York, p 1679.

[13]. Garovic VD et al. Hypertension in pregnancy is associated with a higher incidence of cardiovascular events later in life. American Heart Association 2006 Scientific Sessions; November 15, 2006; Chicago, IL. Abstract 2025.

[14]. Belo L, Caslake M, Gaffney D, Santos-Silva A, Pereira-Leite L, Quintanilha A, et al. Changes in LDL size and HDL concentration in normal and preeclamptic pregnancies. Atherosclerosis 2002;162:425- 32.

[15]. Kaaja R, Laivuori H, Laakso M, Tikkanen MJ, Ylikorkala O. Evidence of a state of increased insulin resistance in preeclampsia. Metabolism 1999;48:892-6.

[16]. Roberts JM. Endothelial dysfunction in preeclampsia. Semin Reprod Endocrinol 1998;16:5-15.

[17]. Isomaa B, Almgren P, Tuomi T, Forsen B, Lahti K, Nissen M, et al. Cardiovascular morbidity and mortality associated with the metabolic syndrome. Diabetes Care 2001;24:683-9.

[18]. Catalano PM, Tyzbir ED, Wolfe RR, Roman NM, Amini SB, Sims EAH. Longitudinal changes in basal hepatic glucose production and suppression during insulin infusion in normal pregnant women. Am J Obstet Gynecol. 1992; 167:913-919.

[19]. Cekmen, M.B., Erbagci, A.B., Balat, A., Duman, C., Maral, H., Ergen, K., Osden, M., Balat, O. and Kuskay, S. (2003). Plasma lipid and lipoprotein concentrations in pregnancy induced hypertension, Clin. Biochem. 36(7), 575-8.

[20]. Reunanen, A., P. Knekt, and R.-K. Aaran (1992) Serum ceruloplasmin level and the risk of myocardial infarction and stroke. Am. J. Epidemiol. 136: 1082-1090

[21]. Isomaa B, Almgren P, Tuomi T, Forsen B, Lahti K, Nissen M, et al. Cardiovascular morbidity and mortality associated with the metabolic syndrome. Diabetes Care 2001;24:683-9.

[22]. Sattar N, Greer IA. Pregnancy complications and maternal cardiovascular risk: opportunities for intervention and screening? BMJ 2002;325:157-60. 